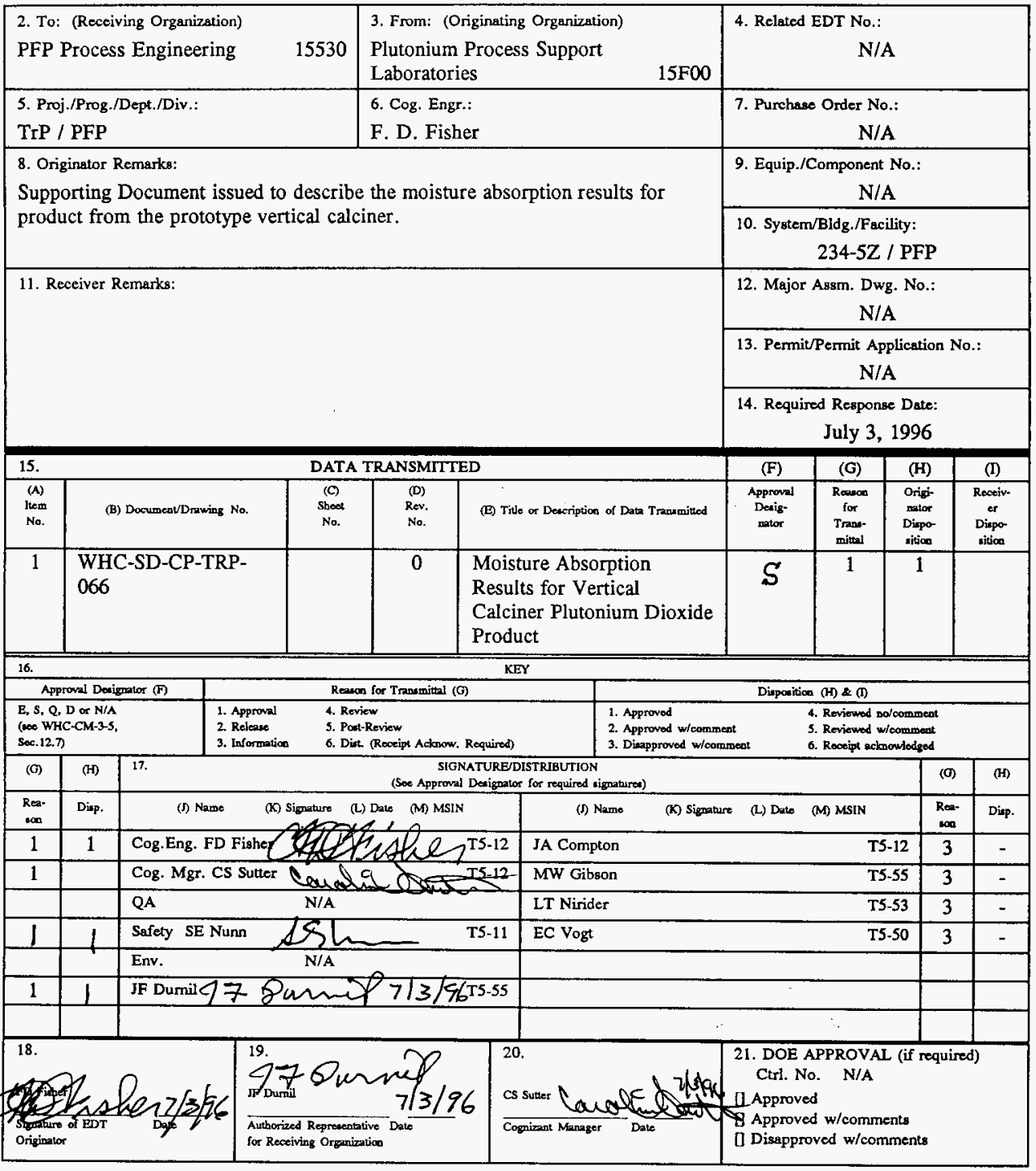

BD-7400-172-2 (04/94) GEF097 


\title{
Moisture Absorption Results for Vertical Calciner Plutonium Dioxide Product
}

\author{
F. D. Fisher and J. A. Compton
}

Westinghouse Hanford Company, Richland, WA 99352

U.S. Department of Energy Contract DE-AC06-87RL10930

$$
\begin{array}{lll}
\text { EDT/ECN: } & 160211 & \text { UC: } 2050 \\
\text { Org Code: } & 15 F 00 & \text { Charge Code: K6137 } \\
\text { B\&R Code: } & \text { EW7003000 } & \text { Total Pages: } 85 \text { \$ }
\end{array}
$$

Key Words: Plutonium Dioxide, Moisture, Absorption, Vertical Calciner, Loss on Ignition

Abstract: A sample of calcined plutonium dioxide was exposed to room air for one week. The sample was weighed daily to determine if the material absorbed moisture from the room air. A random variation of weight was observed after the first day; however, the sample returned to its original weight at the end of the week. The Loss On Ignition for the material increased from 0.439 to 0.544 weight percent during this time. This change is considered inconsequential as the material will normally be packaged for storage within hours of its production.

TRADEMARK DISCLAIMER. Reference herein to any specific commercial product, process, or service by trade name, trademark, manufacturer, or otherwise, does not necessarily constitute or imply its endorsement, recomendation, or favoring by the United states Government or any agency thereof or its contractors or subcontractors.

Printed in the United Stetes of America. To obtain copies of this document, contact: WHC/BCS Document Control Services, P.O. Box 1970, Mailstop K6-08, Richland WA 99352, Phone (509) 372-2420; Fax (509) 376.4989.
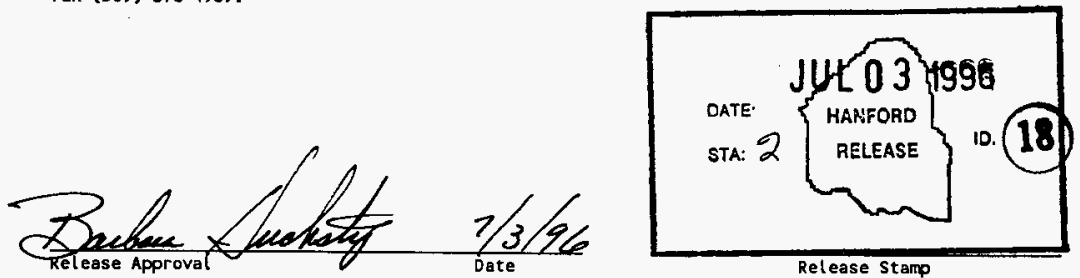

- Approved for Public Release 


\section{MOISTURE ABSORPTION RESULTS FOR VERTICAL CALCINER PLUTONIUM DIOXIDE PRODUCT}

\section{INTRODUCTION}

Plutonium in Hanford's Plutonium Finishing Plant (PFP) is being stabilized by conversion to plutonium dioxide $\left(\mathrm{PuO}_{2}\right)$ for long-term storage per direction from the Defense Nuclear Facilities Safety Board. Moisture must be kept to an acceptably low level in the stored $\mathrm{PuO}_{2}$ to prevent pressurization of the storage cans from radiolysis of the water. The moisture content is considered low enough for safe storage if the $\mathrm{PuO}_{2}$ 's Loss On ignition (LOI) at $950^{\circ} \mathrm{C}$ is less than 0.5 weight percent.

Plutonium nitrate solutions in the PFP are being converted to $\mathrm{PuO}_{2}$ in a vertical direct denitration calciner. Both the prototype and future production calciners operate in gloveboxes ventilated by normal room air, which can be quite humid ( $>60$ percent relative humidity) because the building ventilation is swamp-cooled. Plutonium dioxide is hygroscopic and was formerly processed only in gloveboxes serviced by dried air (dew point lower than $-23.3^{\circ} \mathrm{C}$ ). The older processes, however, operated at temperatures no higher than $500^{\circ} \mathrm{C}$ and the hygroscopicity of $\mathrm{PuO}_{2}$ is known to decrease with higher processing temperature. The use of gloveboxes with normal room air allows a considerable cost saving by avoiding the use of a dried air system, provided the open air handling of the $\mathrm{PuO}_{2}$ does not allow enough moisture absorption to exceed the LOI criterion.

The Plutonium Process Support Laboratories were asked to sample the initial product from the prototype vertical calciner and monitor its weight change over time while open to room air.

\section{PURPOSE AND SCOPE}

The purpose of the test was to confirm that $\mathrm{PuO}_{2}$ calcined in the vertical calciner would not absorb moisture quickly enough to require handling in a dry air glovebox.

This test consisted of weighing one sample of calciner product repeatedly during a one-week period to monitor its weight gain, if any. The relative humidities of the air over time were not recorded as their variance in the future is assumed to be the same as their variance now.

\section{SUMMARY}

The tested sample increased in weight by a maximum of 0.037 percent during the 6-day test period; however, the weights varied up or down during different days and the ending weight was the same as the starting weight. Perhaps most importantly, there was no weight change during the first day. The calciner product's Loss On Ignition (LOI) was shown to change only slightly even after 7 days of exposure to room air. The LOI values were 0.439 weight percent before testing and 0.544 weight percent after testing. 


\section{METHOD}

The tested sample was the third of 3 samples removed from the first batch of vertical calciner product. Sample 3736 was removed from near the bottom of the product collection pot, which means it consisted of some of the very first product to exit the calciner. This initial product was a mixture of freshly calcined $\mathrm{PuO}_{2}$ and $\mathrm{PuO}_{2}$ obtained from PFP Operations after stabilization in the scrap stabilization furnaces for use as the calciner starter bed (the extent of mixing can not be determined). The starter bed and initial calcined product had spent weeks inside the calciner chamber occasionally heated, but always exposed to room air. The valve between the product and the calciner chamber was left open during the 3-day period between the last calciner run and the time of sampling. Sample 3736 had a net weight of $81.42 \mathrm{gm}$ solids with a calculated Pu content of $60.9 \mathrm{gm}$. The sample vial was closed tightly after weighing and left closed until transferred to Glovebox 179-12 for these weighings.

The sample was opened inside Glovebox 179-12 and left open to the room atmosphere flowing through the glovebox for 7 days. The sample was weighed daily except during the weekend.

\section{RESULTS}

The following weights were obtained for Sample 3736 and recorded in the laboratory notebook (Reference 1). Other observations of the weight were made on other days but not recorded in the notebook. The listed weights are gross weights of the sample and vial with its lid.

Date

March 26, 1996

March 27

April 1
Weight (grams)

100.04

100.04

100.07

The maximum weight gain of $0.03 \mathrm{gm}$ during the 7 days is a weight increase of 0.037 percent compared to the starting net weight of $81.42 \mathrm{gm}$ of solids. More importantly, there was no recordable weight gain during the first day of exposure. While not recorded in the laboratory notebook, those performing the weighings indicated that the weight changed up and down from day to day and that it returned to 100.04 at the completion of one week (Reference 2). Two possible explanations for the random weight variances are (1) random error in the balance and (2) reaction to changing absolute humidity in the room air over time (i.e., the saturation moisture content is affected by the surrounding absolute humidity).

The product from the calciner is expected to be packaged for storage within a few hours of its generation and it will be very warm for a good portion of the intervening time. An intervening period of a few days would be expected only in case of long-term emergency evacuations. Regardless of the time between generation and packaging, unsuitable product can be recycled into the calciner for additional processing. 
If the weight gain is assumed to be entirely water, this weight gain is a gain of 0.00166 mole of water. The starting weight of $\mathrm{Pu}$ in Sample 3736 was $60.9 \mathrm{gm}$, which is 0.255 mole $\mathrm{Pu}$. The gain, then, may also be expressed as $0.00166 / 0.255=0.0065$ mole water gained per mole $\mathrm{Pu}$ (an increase of 0.013 in the product's "H/Pu ratio).

Sample 3735 was removed from the same area of the product collection pot at the same time and submitted directly to the PFP Analytical Laboratory (AL) for its LOI analysis. The LOI on Sample 3735 was 0.439 weight percent and the starting LOI for Sample 3736 is assumed to have the same LOI.

Sample 3779 was removed from Sample 3736 after testing and submitted to the PFP AL for LOI determination. This post-exposure LOI was 0.544 weight percent (Reference 3), which exceeds the acceptable LOI criterion of 0.5 percent; however, the remainder of Sample 3736 was returned to the calciner for reheating, as originally planned.

As a check on the accuracy of the results, the following weights for the solids in Sample 3736 are calculated as the "absolutely unremovable" portion of the sample (i.e., an LOI of 0.000 percent) before and after the moisture absorption test:

$$
\begin{aligned}
& \text { Before: } \quad \begin{aligned}
(81.42 \mathrm{gm})(1-0.00439) \\
\text { After: }
\end{aligned}(81.42+0.03 \mathrm{gm})(1-0.00544)
\end{aligned}=81.01 \mathrm{gm}=81.06 \mathrm{gm}
$$

As another check, the weights to be lost from all of Sample 3736 per the LOI results are calculated as follows before and after testing:

$$
\begin{aligned}
& \text { Before: } \begin{array}{c}
(81.42 \mathrm{gm})(0.00439)=0.357 \mathrm{gm} \\
\text { After: }
\end{array}(81.45 \mathrm{gm})(0.00544)=0.443 \mathrm{gm}=0.03 \mathrm{gm}+0.413 \mathrm{gm}
\end{aligned}
$$

These checks show that some analytical error is present in the results, either from the reported LOI values, balance errors, or both. There is also a possibility that part of the $0.03 \mathrm{gm}$ weight gain in Sample 3736 was moisture absorbed onto the glass sample vial, rather than into the sample.

Regardless, the errors are minor. In the first check, the "absolutely unremovable" portion of the "after" sample is only 0.0617 percent less than that of the "before" sample. In the second check, the "after" sample's weight lost would be only $0.056 \mathrm{gm}$ higher $(0.413-0.357$ after subtracting the known weight gain) than the "before" sample's loss, matching the $0.05 \mathrm{gm}$ in the first check, which has no means of obtaining a third decimal place. These checks also show how even a minor error in weighing and/or LOI results can affect whether product is "barely acceptable" or "barely unacceptable" for storage. 


\section{CONCLUSIONS}

The calciner product may be handled in open room air for the time required to package it without affecting the product LOI unless an extraordinary amount of exposure time is realized. Normal handling should be done in a few hours and the test shows no weight gain during the first 24 hours. Extraordinarily long handling times may have a slight effect on the suitability for storage; however, that effect might not be enough to render the product unsuitable for storage.

\section{REFERENCES}

1. Laboratory Notebook WHC-N-967, Volume 1, F. D. Fisher, "Direct Denitration," issued April 13, 1994, pp 43.45.

2. Verbal Communication, M. L. Winstead to J. A. Compton, June 28, 1996.

3. Verbal Communication, L. L. Morrison to J. A. Compton, June 27, 1996. 